\title{
Detection of interferon gamma mRNA in the mucosa of patients with coeliac disease by in situ hybridisation
}

\author{
M Kontakou, R P Sturgess, R T Przemioslo, G A Limb, J M Nelufer, P J Ciclitira
}

\begin{abstract}
In situ hybridisation has been used to study interferon gamma (IFN $\gamma$ ) mRNA expression in the small intestine of patients with coeliac disease. Sections of jejunal biopsies were obtained from five patients with treated and five with untreated coeliac disease and five disease controls. These sections were hybridised with radiolabelled specific DNA oligonucleotide probes. The lamina propria of untreated coeliac disease patients contained a significantly increased number of IFN $\gamma$ producing cells compared with controls but there was no significant difference between the coeliac patients treated with a gluten free diet and controls. The results suggest that IFN $\gamma$ may play a part in the immunopathogenesis of coeliac disease.

(Gut 1994; 35: 1037-1041)
\end{abstract}

Coeliac disease is characterised by gluten induced damage to the small intestinal mucosa, which exhibits villous atrophy, crypt cell hyperplasia, and infiltration of the lamina propria with lymphocytes and plasma cells..$^{1-3}$ There is also an increased ratio of intraepithelial lymphocytes to small intestinal surface enterocytes. ${ }^{45}$ Another important feature of coeliac disease is the enhanced expression of class II major histocompatibility complex antigens. ${ }^{6}{ }^{7}$ In most cases these changes revert to normal on removal of gluten from the diet. It has been suggested that coeliac disease represents an abnormal cellular immune response in genetically susceptible people to the ingestion of cereal peptides, which are as yet unidentified. During this immune response many cytokines which are capable of initiating cellular and molecular changes are released.

Interferon gamma (IFN $\gamma$ ) is produced during immune reactions, mainly by antigen, mitogen, or lectin stimulated $\mathrm{T}$ lymphocytes and also by large granular leukocytes. IFN $\gamma$ has the ability to induce expression of major histocompatibility complex by human enterocytes in vitro 89 and to activate macrophages and natural killer cells.

Studies of the role of IFNy in other enteropathies such as Crohn's disease suggest that there is an increase in the number of IFN $\gamma$ secreting cells compared with controls. ${ }^{10}$ Conflicting results have been reported, however, on interleukin 2 and IFN $\gamma$ expression in the mucosa of patients with Crohn's disease and ulcerative colitis. ${ }^{11-13}$ These results were mainly attributed to the insensitivity of the various methods used. ${ }^{14}$ In coeliac disease, detection of IFN $\gamma$ in paraffin embedded sections of normal and disease mucosa was achieved by an immunohistochemical technique. ${ }^{15}$ It was reported that a relatively large proportion of both intraepithelial and lamina propria lymphocytes in normal small bowel produce IFN $\gamma$. The proportion of lymphocytes that produced IFN $\gamma$ seemed to decrease in untreated coeliac disease patients and returned towards normal in patients on a gluten free diet. The same study, however, reported increased expression of class II major histocompatibility complex antigens on the surface enterocytes of untreated coeliac mucosa, usually associated with increased levels of IFN $\gamma$. It was suggested that although IFN $\gamma$ is probably produced in increased amounts in coeliac disease, it may also be secreted at a higher rate so that less stainable product is available for detection. To evaluate this theory cytokine production in tissues should be assessed by localising not only protein expression but also mRNA levels. ${ }^{16} 17$

We have used a radioactive in situ hybridisation technique to detect and localise mRNA expression of IFN $\gamma$ in jejunal biopsies specimens from patients with coeliac disease, in order to study the role of this particular cytokine in the pathology of the disease.

\section{Methods}

\section{PATIENTS AND BIOPSY SPECIMENS}

Peroral jejunal biopsy specimens were taken from adult patients with coeliac disease on a normal diet $(n=5$, mean age $=45$ years, range $=34-56)$, on a gluten free diet $(n=5$, mean age $=49 \cdot 4$, range $=30-66$ ), and from controls $(n=5$, mean age $=56$, range $=31-75)$ as part of their diagnostic investigations. The controls were subsequently diagnosed as having the irritable bowel syndrome and all had normal jejunal morphology. The diagnosis of coeliac disease was made according to ESPGAN criteria. ${ }^{18}$ All treated patients had been on a gluten free diet for at least two years and had normal or near normal villous architecture. The biopsy specimens were obtained using a Quinton multiple biopsy instrument. Tissue specimens were immediately orientated, embedded in optimal cutting temperature compound (Cryo-M-bed; Brights, Huntington, UK) snap frozen in liquid nitrogen cooled isopentane, and stored in liquid nitrogen until processed. Cryostat 
TABLE I Oligonucleotides with DNA sequences complementary to interferon gamma $m R N A$ used in this study

\begin{tabular}{|c|c|}
\hline IFN $\gamma .1$ & $\begin{array}{l}{ }^{5} \text { AAA GAG TTC CAT TAT CCG CTA CAT } \\
\text { TCG AAT }^{3}{ }^{\prime}\end{array}$ \\
\hline IFN $\gamma .2$ & $\begin{array}{l}\text { 5'GTA TTG CTT TGC GTT GGA CAT TCA } \\
\text { AGT CAG }^{3}\end{array}$ \\
\hline $\mathrm{IFN} \gamma \cdot 3$ & 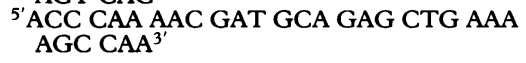 \\
\hline
\end{tabular}

sections were cut at $5 \mu \mathrm{m}$ on a Bright open-top cryostat at $-20^{\circ} \mathrm{C}$ and collected onto glass slides that had been washed with distilled water rendered RNase free by diethylpyrocarbonate treatment ${ }^{19}$ and precoated with poly-L-lysine. Sections were briefly fixed in acetone for five minutes and stored at $-20^{\circ} \mathrm{C}$.

PROBES AND LABELLING METHOD

DNA oligonucleotide probes were prepared in-house using a Beckman synthesiser. IFN $\gamma$ mRNA detection was achieved using a mixture of three probes, each 30 bases long, with cDNA sequences coded by three different exon regions of the IFN $\gamma$ gene (sequence published by Gray and Goeddel). ${ }^{20}$ The probes used in this study and their sequence are listed in Table I. Specificity of the probes was confirmed by northern blotting of mRNA coding for IFN $\gamma$, isolated from blood mononuclear cells that had been cultured in the presence of $1 \mu \mathrm{g} / \mathrm{ml}$ phytohaemmaglutinin or $10 \mu \mathrm{g} / \mathrm{ml}$ concanavalin A according to Maniatis et al. ${ }^{19}$ Computer analysis of the sequences was achieved using the DNASIS program.

Four pmol of each oligonucleotide were labelled by the addition of an $\alpha^{35}$ S dATP 'tail' to the 3 ' termini using terminal deoxynucleotidyl transferase, according to the supplier's protocol (Promega). After the labelling reaction the probes were purified by passing them through a prepacked Sephadex G-50 DNA grade column (Pharmacia), and their specific activity was measured using a Rackbeta liquid scintillation counter. The specific activity of the probes was not less than $1 \times 10^{8} \mathrm{cpm} / \mu \mathrm{g}$.

\section{PRETREATMENT AND HYBRIDISATION}

The method used was a modification of that previously described by Hamid et al. ${ }^{21}$ All solutions used were made up with $\mathrm{RNase}$ free distilled water. Sections, kept at $-20^{\circ} \mathrm{C}$, were air dried for at least one hour before fixation with freshly prepared $4 \%(w / v)$ paraformaldehyde in phosphate buffered saline $\mathrm{pH} 7 \cdot 4$ for 15 minutes, followed by two washes in $15 \%$ (w/v) sucrose in phosphate buffered saline for 10 minutes each. Pretreatments also involved incubation with $0.3 \%(\mathrm{v} / \mathrm{v})$ Triton-X-100 in phosphate buffered saline for 10 minutes, followed by incubation at $37^{\circ} \mathrm{C}$ with $1 \mu \mathrm{g} / \mathrm{ml}$ proteinase $\mathrm{K}$ for 30 minutes, postfixation in $0.4 \%(w / v)$ paraformaldehyde for 10 minutes and treatment with $0 \cdot 1 \mathrm{M}$ triethanolamine containing $0.25 \%(\mathrm{v} / \mathrm{v})$ acetic anhydride for 10 minutes. The sections were prehybridised in a mixture of $2 \times$ saline-sodium citrate buffer, $50 \%$ (v/v) formamide and $1 \times$ Denhardt's solution at $37^{\circ} \mathrm{C}$ for one hour and then hybridised with $2 \mathrm{ng}$ of labelled probe overnight at $37^{\circ} \mathrm{C}$ in a solution containing: $2 \times$ sodium citrate buffer, $50 \%(\mathrm{v} / \mathrm{v})$ formamide, $0.4 \mathrm{mg} / \mathrm{ml}$ denatured sheared salmon sperm DNA and 10\% (w/v) dextran sulphate (MW 500 000). Posthybridisation stringency washes were carried out at $39^{\circ} \mathrm{C}$, for 30 minutes each, in $2 \times$ sodium citrate buffer, $1 \times$ sodium citrate buffer $+50 \%$ formamide and $0 \cdot 1 \times$ sodium citrate buffer. Sections were dehydrated serially in $60 \%$, $90 \%$, and $95 \%$ ethanol and dried at room temperature.

\section{CONTROLS}

A sense sequence complementary to the IFN $\gamma .1$ probe was used as a negative control. An oligo dT probe was also used for the detection of total mRNA and served as a positive control. To establish whether the hybrids formed were indeed RNA/DNA, some sections were treated with either DNase-free RNase (negative hybridisation signal) or RNase-free DNase (no effect on hybridisation) after the proteinase $\mathrm{K}$ treatment. Sections were incubated at $37^{\circ} \mathrm{C}$ with either of the two enzymes at a concentration of $600 \mathrm{U} / \mathrm{ml}$ for 30 minutes.

\section{AUTORADIOGRAPHY}

Dried sections were dipped in Ilford K5 photographic gel emulsion that had been diluted $1: 1$ in prewarmed distilled water, left to dry in a dark room for approximately two hours, and then incubated at $4^{\circ} \mathrm{C}$ in a lightproof box containing silica gel for five days. Slides were developed in $44 \mathrm{~g} / 1$ Dektol solution (Kodak) for two minutes, washed briefly in distilled water and fixed in 30\% (w/v) sodium thiosulphate at $4^{\circ} \mathrm{C}$ for 15 minutes. Finally, the slides were thoroughly rinsed in running tap water and counterstained with Mayer's haematoxylin.

\section{QUANTITATION AND STATISTICAL ANALYSIS}

The number of positive cells within the lamina propria were counted per unit area by using an eye piece graticule $\left(1 \mathrm{~mm}^{2}\right)$ under $\times 400$ magnification. At least five consecutive areas of the lamina propria (within and below the villi going to the deeper lamina propria) were counted for each section and for each specific probe a minimum of two sections were prepared and scored blindly for each patient. Each investigation with specific probes was repeated twice for all patients and the mean taken. The results were expressed as the mean number of positive cells per unit area $(0.0025$ $\mathrm{mm}^{2}$ ). The standard deviation of the mean was calculated for each group and the Student's $t$ test was used to compare results for different patient groups.

Morphometric measurements were performed by an eyepiece micrometer under $\times 200$ magnification. For each section a minimum of five measurements of villous height to crypt depth ratio (V/C) were 


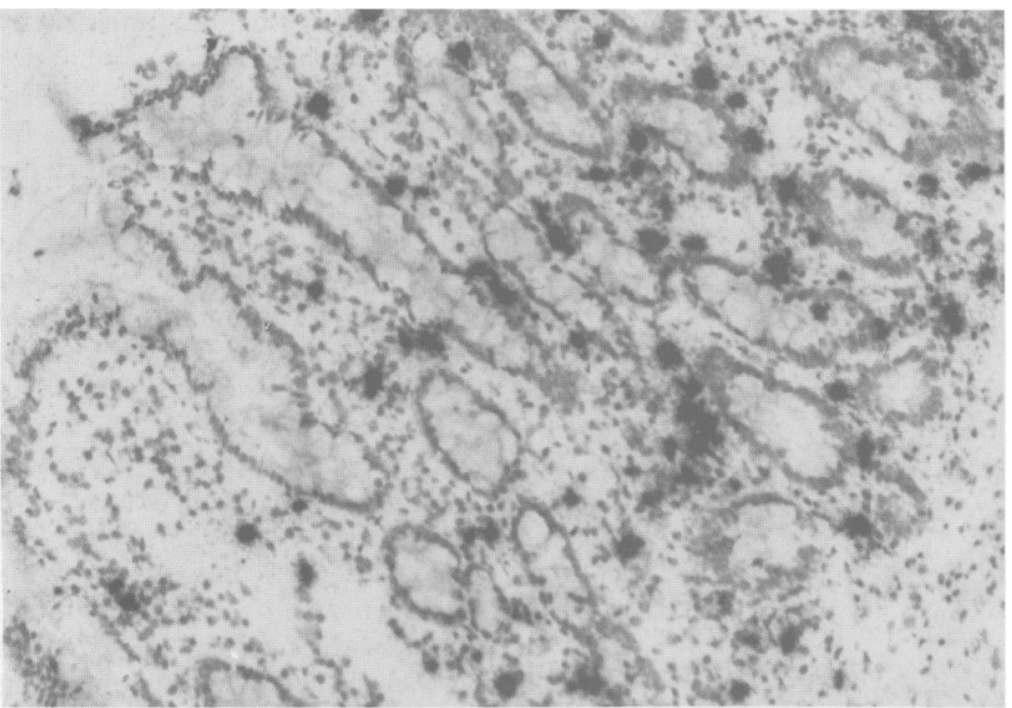

Figure 1: Fejunal biopsy specimen from an untreated coeliac disease patient showing the distribution of cells expressing mRNA for IFN $y$. Positive cells are abundant in the lamina propria but not the epithelium (original magnification $\times 200$ ).

made and the mean and standard deviation calculated.

\section{Results}

IFN $\gamma$ MRNA EXPRESSION

In situ hybridisation, using ${ }^{35}$ S-labelled antisense oligonucleotide probe for IFN $\gamma$, showed that numerous cells infiltrating the jejunal mucosa contained IFNy mRNA. Positively stained cells were found mainly in the superficial lamina propria, and occasionally in the deeper lamina propria. There was no staining of the intraepithelial lymphocytes or surface enterocytes. The results of one untreated patient and one with normal mucosa, are shown in Figures 1 and 2 respectively. A similar label intensity was obtained in the mucosa of the other patients within the groups. The number of IFN $\gamma$ expressing cells in the lamina propria of the untreated coeliac disease patients was increased significantly

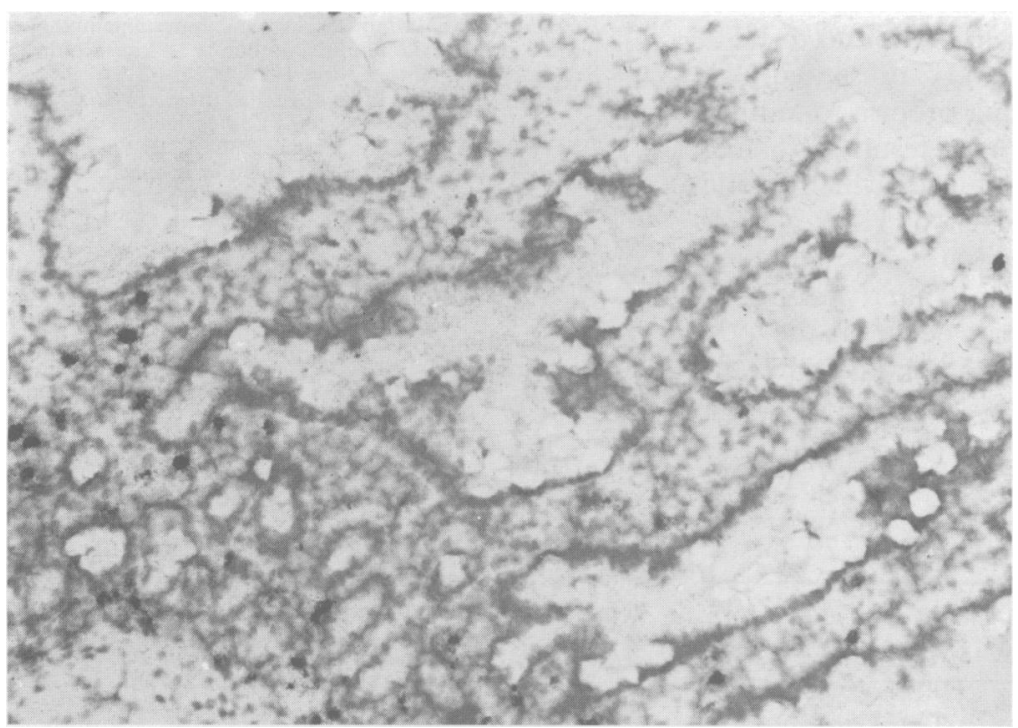

Figure 2: Distribution of IFN $\gamma$ mRNA expressing cells in normal jejunal mucosa. Fewer positive cells are seen compared with untreated coeliac mucosa (Fig 1), but still very clearly identified in the lamina propria (original magnification $\times 200$ ). $(p<0.001)$ compared with treated patients and controls. The difference in the numbers of IFN $\gamma$ mRNA expressing cells between treated coeliac patients and controls was not significant. These results are summarised in Table II, together with the morphometric analysis for each group. The untreated coeliac patients showed a high degree of villous atrophy (ratio of villous height to crypt depth $\leqslant 1$ ), while the treated patients had near normal mucosal morphology (normal ratio of villous height to crypt depth between 3-5).

\section{IN SITU HYBRIDISATION CONTROLS}

The absence of hybridisation signal, in all patient groups, with the ${ }^{35} S$-labelled sense probe (Fig 3) indicated that the binding of the IFN $\gamma$ antisense probe was specific. Treatment with RNase, but not DNase, before hybridisation also resulted in failure of hybridisation with labelled sense and antisense probe, indicating that the hybridisation was indeed on mRNA. Hybridisation with oligo dT probes for assessment of total mRNA was detected in all biopsies.

\section{Discussion}

In this study we have shown that IFN $\gamma$ is expressed by lamina propria cells, increasingly so in active coeliac disease, by assessing the presence of cytoplasmic messenger RNA. IFN $\gamma$ is known to be produced mainly by activated $T$ lymphocytes and most of those found in the lamina propria are of the $\mathrm{CD}^{+}$ (helper/inducer) subset. ${ }^{22}$ Although the phenotype of the positive cells was not identified in this study, the localisation of these cells in the lamina propria indicates that IFN $\gamma$ is probably expressed by $\mathrm{CD} 4^{+} \mathrm{T}$ cells. Recent studies on activated $T$ lymphocytes in coeliac disease reported the induction of proliferative activation of $\mathrm{CD}^{+}$(suppressor/cytotoxic) intraepithelial lymphocytes but non-proliferative activation of lamina propria $\mathrm{CD}^{+}$ $T$ cells. ${ }^{23}$ It was suggested that gluten specific $\mathrm{CD}^{+}$lamina propria $\mathrm{T}$ cells probably produce cytokines that induce epithelial crypt cell hyperplasia as well as local proliferation of intraepithelial lymphocytes. This agrees with reports in Crohn's disease that IFNy and interleukin 2 are produced by activated $\mathrm{CD}^{+}$ cells. ${ }^{14}$ The same report suggested that there is a continuing delayed hypersensitivity response within the mucosa in Crohn's disease which may be responsible for the pathological damage of the mucosa. In mice, IFN $\gamma$ is synthesised by the TH1 subpopulation of $\mathrm{CD}^{+}$cells, which have been shown to cause a delayed hypersensitivity response, partially ascribed to the production of IFN $\gamma$, in response to local presentation of antigen. ${ }^{24}$

IFN $\gamma$, as well as tumour necrosis factor $\alpha$, has been shown to be a capable effector molecule in immune destruction of self tissues, ${ }^{25}$ and to reduce the epithelial function of the human colon carcinoma cell line HT29 cl 19A. ${ }^{26}$ Both cytokines can destroy target tissues of known autoimmune responses, 


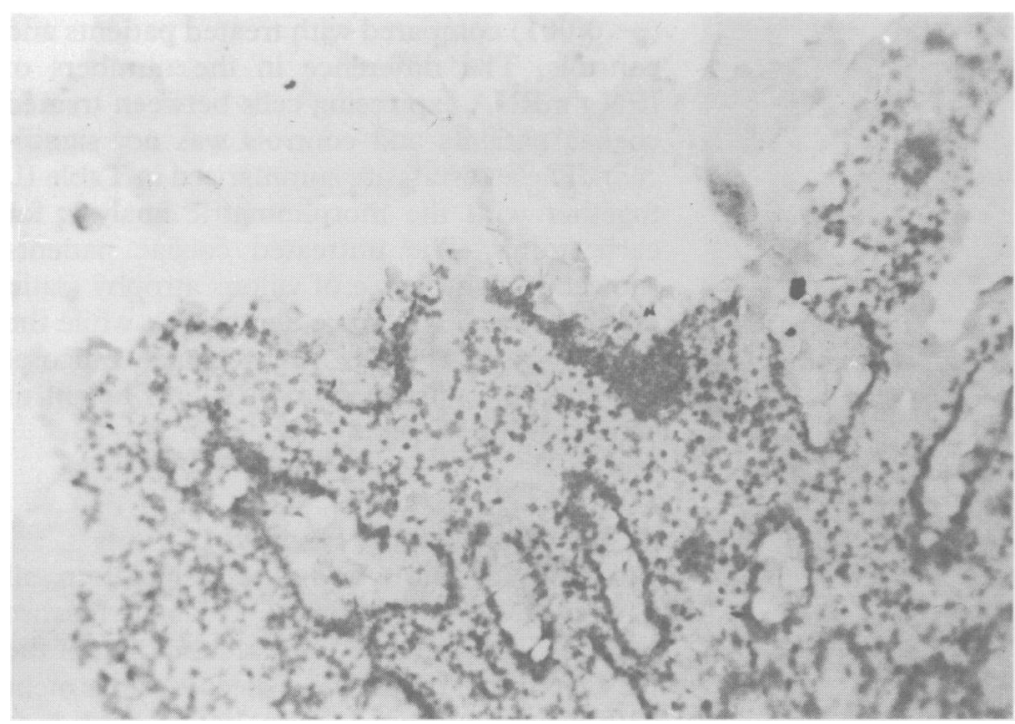

Figure 3: Fejunal biopsy from an untreated coeliac disease patient showing absence of hybridisation signal with the sense IFN $\gamma$ probe, used as a negative control (original magnification $\times 200$ ). lamina propria and the epithelium, and also by direct cytotoxic mechanisms.

The initial event in the action of the interferons is their binding to specific receptors on the cell surface, present on most cells. After the binding, the interferon receptor complexes are internalised by receptor mediated endocytosis. ${ }^{32}$ For this reason, the localisation of the IFN $\gamma$ product by immunohistochemical methods has been very difficult to interpret, because it will also identify target cells as well as any complexes passively uptaken by phagocytes and mucosal epithelial cells. ${ }^{33}$ Cytokine production can also be affected by competitive inhibition of cytokine receptor by specific and non-specific receptor antagonists. This mechanism has been well described for interleukin $1 .{ }^{34}$ One or more of the mechanisms described above could explain the conflicting results between the present study using in situ hybridisation and a previous report using immunohistochemistry. ${ }^{15}$ Although, mRNA levels can also be misleading as some cytokines are regulated post-transcriptionally, in situ hybridisation remains a very powerful technique enabling the localisation of the cellular synthesis of various cytokines. The results of the present study support the hypothesis that the primary events in the immunopathogenesis of coeliac disease occur in the lamina propria and suggest that IFN $\gamma$ is probably associated with the damage to the villi that is observed in this condition.

The authors wish to thank the St Thomas's Research (Endowments) Committee, the Nutricia Research Fund, and the Jean Shanks Research Foundation.

1 Marsh MN. Mucosal pathology in gluten sensitivity. In: Marsh MN, ed. Coeliac Disease. Oxford: Blackwell Scientific Publications, 1992: 136-91.

2 Marsh MN. The morphology and immunopathology of the ejunal lesion in gluten-sensitivity. Eur $\mathcal{f}$ Gastroenterol Hepatol 1991; 3: 163-8.

3 Ciclitira P, Ellis H, Wood G, Howdle P, Losowsky M. Secretion of gliadin antibody by coeliac jejunal mucosal biopsies cultured in vitro. Clin Exp Immunol 1986; 64: 119-24.

4 Spencer J, MacDonald T, Walker-Smith J, Ciclitira P, Isaacson P. Changes in intra-epithelial lymphocyte subIsaacson $\mathrm{P}$. Changes in intra-epithelial lymphocyte subpopulations in coeliac disease and enteropathy associated
T-cell lymphoma (malignant histiocytosis of the T-cell lymphoma (malignant

5 Brandtzaeg P, Halstensen T, Kett K, Kracci P, Kvale D, Rognum $\mathrm{T}$, et al. Immunobiology and immunopathology of human gut mucosa: humoral immunity and intraepithelial lymphocytes. Gastroenterology 1989; 97: 1562-84.

6 Kagnoff MF. Genetic basis of coeliac disease: role of HLA enes. In: Marsh MN, ed. Coeliac Disease. Oxford: Blackwell Scientific Publications, 1992: 215-38.

7 Ciclitira P, Sturgess R. Clinicopathologic mechanisms in celiac disease. Curr Opinion Gastroent 1992; 8: 262-7.

8 Sollid L, Gaudernack G, Markussen G, Kvale D, Brandtzaeg P, Thorsby E. Induction of various HLA class II molecules in a human colonic adenocarcinoma cell line. Scand $\mathcal{F}$ Immunol 1987; 25: 175-80.

9 Sturgess R, Hopper L, Spencer J, Hung C, Nelufer J, Ciclitira P. Effects of interferon- $\gamma$ and tumour necrosis fictitira P. Effects of interferon- $\gamma$ and tumour necrosis factor- $\alpha$ on epithelial HLA class-II expression on jejunal
mucosal biopsy specimens cultured in vitro. Scand $f$ mucosal biopsy specimens cultur

10 Fais S, Capobianchi M, Pallone F, Di Marco P, Boirivant $M$, Dianzani F, et al. Spontaneous release of interferon $\gamma$ by intestinal lamina propria lymphocytes in Crohn's disease. Kinetics of in vitro response to inteferon $\gamma$ inducers. Gut 1991; 32: 403-7.

11 Kusugami K, Yongman K, West G, Fiocchi C. Intestinal immune reactivity to interleukin 2 differs among Crohn's disease, ulcerative colitis, and controls. Gastroenterology 1989; 97: 1-9.

12 Ouyang O, El-Youssef M, Yen-Lieberman B, Sapatnekar W, Youngman K, Kusugami K, et al. Expression of HLA$\mathrm{DR}$ antigens in inflammatory bowel disease mucosa: role DR antigens in infammatory bowel disease mucosa: role of intestinal lamina propria mononuclear cell-der

13 MacDonald T, Hutchings P, Choy M, Murch S, Cooke A. Tumour necrosis factor-alpha and interferon-gamma- 
production measured at the single cell level in normal and production measured at the single cell level in normal and 301-5.

14 Breese E, Braegger C, Corrigan C, Walker-Smith J, MacDonald T. Interleukin-2 and interferon-y-secreting T cells in normal and diseased human intestinal mucosa. Immunology 1993; 78: 127-31.

15 Al-Dawoud A, Nakashabendi I, Foulis A, McMowat A Immunohistochemical analysis of mucosal gamma-interferon production in coeliac disease. Gut 1992; 33. 1482-6.

16 Dallman M, Montgomery R, Larsen C, Wanders A, Wells A. Cytokine gene expression: analysis using northern blotting, polymerase chain reaction and in situ hybridisation. Immunol Rev 1991; 119: 163-79.

17 Ogilvie A, Wood N, Dickens E, Wojtacha D, Duff G. In situ hybridisation. Ann Rheum Dis 1990; 49: 434-9.

18 Meeuwisse GW. Diagnostic criteria in coeliac disease (European Society of Paediatric Gastroenterology). Acta Paed Scand 1970; 59: 461-3.

19 Sambrook J, Fritsch E, Maniatis T. Molecular Cloning: a laboratory manual. New York: Cold Spring Harbo Laboratory Press, 1989: 7.4

20 Gray PW, Goeddel DV. Molecular biology of interferongamma. In: Lymphokines. New York: Academic Press Inc, 1987.

21 Hamid $\mathrm{O}$, Azzawi $M$, Ying S, Maqbel $R$, Wardlow A Corrigan C, et al. Expression of mRNA for interleukin-5 in mucosal bronchial biopsies from asthma. $\mathcal{F}$ Clin Invest 1991; 87: 1541-6.

22 MacDonald T. T cell-mediated intestinal injury. In: Marsh M, ed. Coeliac disease. Oxford: Blackwell Scientific $\mathrm{M}$, ed. Coeliac disease. Oxf

23 Halstensen T, Brandtzaeg P. Activated T lymphocytes in celiac lesion: non-proliferative activation (CD25) of $\mathrm{CD} 4+\alpha / \beta$ cells in the lamina propria but proliferatio $(\mathrm{Ki}-67)$ of $\alpha / \beta$ and $\gamma / \delta$ cells in the epithelium. Eur $\mathcal{f}$ Immunol 1993; 23: 505-10.
24 Mosmann T, Coffman R. Heterogeneity of cytokine secreting patterns and functions of helper T cells. Adv Immunol 1989; 46: 111-7.

25 Deem R, Shanahan F, Targan S. Triggered human mucosal $T$ cells release tumour necrosis factor-alpha and interferon-gamma which kill human colonic epithelial cells. Clin Exp Immunol 1991; 83: 79-84.

26 Hiribarren A, Heyman M, L'Helgouac'h A, Dejeux J. Effect of cytokines on the epithelial function of the human colon carcinoma cell line HT29 cl 19A. Gut 1993; 34: 616-20.

27 Cambell I, Iscaro A, Harrison L. IFN $\gamma$ and tumour necrosis factor $\alpha$ cytotoxicity to murine islets of langerhans. Immunol 1988; 141: 2325-31.

28 Cerf-Bensussan N, Quaroni A, Kurnick J, Bhan A Intraepithelial lymphocytes modulate Ia expression by intestinal epithelial cells. f Immunol 1984; 132: by intestinal epithelial cells. $\mathcal{F}$ Immunol 1984; 132:

29 Madara J, Stafford J. Interferon- $\gamma$ directly affects barrier function of cultured intestinal epithelial monolayers. f Clin Invest 1989; 83: 724-7.

30 MacDonald T, Spencer J. Evidence that activated T cells play a role in the pathogenesis of enteropathy in human small intestine. $\mathcal{F} \operatorname{Exp}$ Med 1988; 167: 1341-9.

31 Sturgess R, Kontakou M, Spencer J, Hooper L, Makgoba $M$, Ciclitira P. Effects of Interferon- $\gamma$ and Tumour necrois factor- $\alpha$ on ICAM-1 expression on jejunal mucosal biopsies cultured in vitro. Gut 1993; 34 (1): S31.

32 Oppenheim J, Ruscetti F, Faltynek C. Cytokines. In: Stites $\mathrm{D}$, Terr A, eds. Basic and clinical immunology. Appleton and Lange, 1988: 78-100.

33 Stamp G, Poulsom R, Chung L, Keshav S, Jeffery R, Longcroft $\mathrm{J}$, et al. Lysozyme gene expression in Inflammatory Bowel Disease. Gastroenterology 1992; 103: $532-8$

34 Seckinger $\mathrm{P}$, Lowenthal J, Williamson $\mathrm{K}$, Dayer J, MacDonald $\mathrm{H}$. A urine inhibitor of interleukin 1 activity that blocks ligand binding. F Immunol 1987; 139: 1546-9. 